\title{
The Mystification of Digital Technology in Norwegian Policies on Archives, Libraries and Museums: Digitalization as Policy Imperative
}

\author{
By Erik Henningsen \& Håkon Larsen
}

\begin{abstract}
In this article, we investigate how digitalization has attained the role of policy imperative in the culture sector, and how the imperative is influencing contemporary policy discourses on archives, libraries and museums (ALM-organizations) in Norway. We have analyzed policy documents issued by state authorities within the Norwegian ALM-sector since the time around the turn of the century, and demonstrate through the analysis that one must take three types of cultural processes into consideration in order to understand how digitalization has attained the status as policy imperative. Each of the cultural processes amounts to a form of mystification. Firstly, one must understand that digitalization's ascendancy into a policy imperative is in part a process of imitation, of other countries and societal sectors. Secondly, one must take into account the conceptual framing of the policy discourse, in particular in relation to the epochalist vision that structure the discourse. Thirdly, one must take into account the process of fetishism which is at work in this policy discourse. Combined, these processes lead to digitalization being perceived as a force which is external to social relations, dictating action on the part of actors working within the sector. As such, digitalization comes effectively to serve as an overarching policy imperative in the culture sector.
\end{abstract}

Keywords: Digitalization, Cultural Policy, Cultural Heritage, Cultural Sociology, ALM, Norway.

Henningsen, Erik and Håkon Larsen: "The Mystification of Digital Technology in Norwegian Policies on Archives, Libraries and Museums: Digitalization as Policy Imperative", Culture Unbound, Volume 12, Issue 2, 2020: 332-350. Published by Linköping University Electronic Press: http://www.cultureunbound.ep.liu.se 


\section{Introduction}

In tandem with the evolution of the Internet and information technology, a complex assemblage of projects and programs of digitalization (or "mass digitization") of cultural heritage has emerged over the past decades (Thylstrup 2019). This comprises global initiatives, modelled on the idea of a universal library containing all the world's knowledge. It also comprises territorializing initiatives, such as the European Union's Europeana project, and programs for the digitalization of cultural heritage promoted by national governments. In a recent article Valtysson (2017) examines discourses on the digitalization of cultural heritage in Danish cultural policy, noting that aims of administrative effectiveness and preservation take precedence over user engagement and access. Other studies note that collections documenting minorities and marginalized groups have been exempted from national strategies of digitalization of cultural heritage (Caswell, Harter \& Jules 2017). In this article, we will study the role of digitalization in contemporary discourses on cultural policy in Norway. In doing so, we will pay specific attention to the role the concept of digitalization plays in national policies related to archives, libraries and museums (ALM-organizations), although from a different perspective than the abovementioned studies.

Our aim in the pages that follow is not to evaluate the content of policies and programs of digitalization in the Norwegian culture sector, e.g. with regards to the extent to which these promote and prioritize user engagement or whether they transcend or affirm inherited nationalizing programs of cultural policy. Rather, what we aim for is to identify and specify cultural processes that lead to the emergence and solidification of digitalization as a policy imperative in discourses on cultural policy. We do so on the assumption that a careful consideration of cultural policy discourses on digitalization within one country can yield insights regarding the constitution of digitalization as a policy imperative that are of high relevance in other national and international contexts. Moreover, we assume that this analytical exercise can yield insights that are of relevance to the general understanding of processes of formation of policy discourses. To study the emergence of digitalization as a policy imperative, we have analyzed all relevant policy documents issued by Norwegian state authorities within the ALM-sector since the time around the turn of the century. By studying these documents, we have been able to trace the history and development of the discourse on digitalization of the ALM-sector. We have investigated when digital technology became a topic within the discourse and when it achieved the status of an imperative influencing every discussion on the future of ALM-organizations.

Of course we are not the first to discuss the emphasis that is placed on digitalization in the culture sector. Other studies have noted how digitalization take on the character of a cultural and moral imperative within this sector (Borghi 
\& Karapapa 2013, Thylstrup 2019). ${ }^{1}$ While clearly related, our use of the concept "policy imperative" differs from these studies in that it not merely affirms the priority placed on digitalization within cultural policy discourses and point to the arguments on which this is founded. Rather, the concept is intended as a tool for furthering theoretical understanding of how concerns, values or principles are elevated into obligatory and unquestionable reference points in cultural policy discourse, as well as in other domains of policy. We seek, in other words, to address a feature of cultural policy discourse that has a broader significance than its present preoccupation with digitalization: the tendency that certain issues take on a self-explanatory character as calls for action and become overriding concerns of policy discourse at particular times and places. If policy actors are to be taken seriously within these discourses, they must respond to these imperatives, if not in practical action, so at least in words. As Fidjestøl (2015) notes, cultural policy always tends to revolve around an "ultimate value", but the nature of these values changes over time. While there are many practical and moral reasons that digitalization is a pressing concern of cultural policy, it is but one of a range of issues (e.g. cultural diversity, globalization, freedom of expression, access to culture) that potentially could have taken its place as policy imperative. And, probably, in a not too distant future, digitalization will be superseded by another issue as the policy imperative of the culture sector. This begs the question of how and by what forms of cultural processes digitalization has attained the role of a policy imperative.

In order to understand how digitalization has become a policy imperative within this field of cultural policy, we will show that one must take several types of cultural processes into consideration, all of which represents a form of mystification of digitalization. First, digitalization's ascendancy into a policy imperative can be viewed as a process of imitation or "mimetic isomorphism" (DiMaggio \& Powell 1983). Such processes can occur at various levels of organization, including at the international level. According to Dahl and Helseth (2006), imitation of policies from other countries has been one of the principal mechanisms shaping Norwegian cultural policy. As we will demonstrate, this applies to the case of digitalization as well. Second, to understand its role as a policy imperative in the ALM policy field, one must consider the conceptual framing of the discourse on digitalization and in particular the diagnostic and prognostic visions that structure the discourse (cf. Lakoff \& Johnson 1980, Snow \& Benford 1988). Proceeding along these lines, we highlight the epochalist framing of the discourse on digitalization and how digitalization at varying moments emerge as a potential threat to the continued existence of actors within the sector or as a utopian promise of future prosperity. Even though the analysis of mimetic processes, and of the conceptual framing of discourses on digitalization, can take us some distance toward understanding how 
digitalization is constituted as a policy imperative in the ALM-field, to arrive at a fuller understanding of how digitalization attains the role of policy imperative it is necessary to take a third type of cultural process into consideration, namely that of fetishism (Marx 1905, Graeber 2005). As a fetishized object, digitalization is perceived as an external force to social relations, dictating action on the part of actors working within the sector. Through these processes of mystification (imitation, epochalism, fetishism) in cultural policy discourse, digitalization is constituted as an effective policy imperative.

\section{Digitalization and Norwegian Policies on Archives, Libraries and Museums}

Discourses on digitalization have been around for several decades, but in the Norwegian policies on archives, libraries and museums this is a relatively recent topic. In policy documents pertaining to this field from the 1980s and early 1990s digitalization is barely mentioned. However, as is demonstrated by our study, in the period from the late 1990s until the present, digitalization was firmly put on the agenda in discourses on ALM-organizations.

In this section, we briefly discuss the main findings from our study of Norwegian state issued policy documents that deals with cultural heritage and digitalization. The corpus of documents under consideration includes all Norwegian white papers related to the subject, which comprises a total of 7 documents, written over a time span of 14 years (1999-2013). In addition, we have also studied two reports written by experts on the request of the Ministry of Culture. Information on the documents making up the data for this study is presented in table 1.To allow the reader to trace the emergence of digitalization as a discursive topic within the ALM-field, the documents will be briefly presented in a chronological manner, before we analyze them as a cluster.

\begin{tabular}{|l|l|l|l|}
\hline Year & Title (Norwegian/English) & $\begin{array}{l}\text { Place of } \\
\text { publication }\end{array}$ & $\begin{array}{l}\text { Type of } \\
\text { document }\end{array}$ \\
\hline 1996 & $\begin{array}{l}\text { NOU 1996:7: Museum, mangfald, minne, } \\
\text { møtestad/Museum, Diversity, Memory, } \\
\text { Meeting-place }\end{array}$ & $\begin{array}{l}\text { Oslo: Ministry } \text { Culture } \\
\text { paper }\end{array}$ \\
\hline
\end{tabular}




\begin{tabular}{|c|c|c|c|}
\hline 1999 & $\begin{array}{l}\text { St.meld. nr. } 22 \text { (1999-2000) Kjelder } \\
\text { til kunnskap og oppleving. Om arkiv, } \\
\text { bibliotek og museum i ei IKT-tid og } \\
\text { om bygningsmessige rammevilkår på } \\
\text { kulturområdet/ Sources of knowledge } \\
\text { and experience. On archives, libraries and } \\
\text { museums in an ICT-age, and on housing } \\
\text { infrastructure in the culture sector }\end{array}$ & $\begin{array}{l}\text { Oslo: } \\
\text { Ministry of } \\
\text { Culture }\end{array}$ & $\begin{array}{l}\text { White } \\
\text { paper }\end{array}$ \\
\hline 2003 & $\begin{array}{l}\text { St.meld. nr. } 48 \text { (2002-2003) Kulturpolitikk } \\
\text { fram mot 2014/Cultural Policy Towards } \\
2014\end{array}$ & $\begin{array}{l}\text { Oslo: Ministry } \\
\text { of Culture and } \\
\text { Church Affairs }\end{array}$ & $\begin{array}{l}\text { White } \\
\text { paper }\end{array}$ \\
\hline 2006 & $\begin{array}{l}\text { Kulturarven for alle-digitalisering i } \\
\text { abm-sektoren/ Cultural Heritage for All- } \\
\text { Digitalization in the ALM-Sector }\end{array}$ & $\begin{array}{l}\text { Oslo: ALM- } \\
\text { Development } \\
\text { Directorate }\end{array}$ & Report \\
\hline 2009 & $\begin{array}{l}\text { St.meld. nr. } 24 \text { (2008-2009) Nasjonal } \\
\text { strategi for bevaring og formidling av } \\
\text { digital kulturarv/ National Strategy for } \\
\text { Maintenance and Dissemination of Digital } \\
\text { Cultural Heritage }\end{array}$ & $\begin{array}{l}\text { Oslo: Ministry } \\
\text { of Culture and } \\
\text { Church Affairs }\end{array}$ & $\begin{array}{l}\text { White } \\
\text { paper }\end{array}$ \\
\hline 2009 & $\begin{array}{l}\text { St.meld. nr. } 23 \text { (2008-2009) Bibliotek. } \\
\text { Kunnskapsalmenning, møtestad, og } \\
\text { kulturarena i ei digital tid/Libraries. Public } \\
\text { Knowledge, Meeting Place and Cultural } \\
\text { Arena in a Digital Age }\end{array}$ & $\begin{array}{l}\text { Oslo: Ministry } \\
\text { of Culture and } \\
\text { Church Affairs }\end{array}$ & $\begin{array}{l}\text { White } \\
\text { paper }\end{array}$ \\
\hline 2009 & $\begin{array}{l}\text { St.meld. nr. } 49 \text { (2008-2009) Framtidas } \\
\text { museum. Forvaltning, forskning, } \\
\text { formidling, fornying/The Museum of } \\
\text { the Future. Administration, Research, } \\
\text { Dissemination, Renewal }\end{array}$ & $\begin{array}{l}\text { Oslo: Ministry } \\
\text { of Culture and } \\
\text { Church Affairs }\end{array}$ & $\begin{array}{l}\text { White } \\
\text { paper }\end{array}$ \\
\hline 2012 & $\begin{array}{l}\text { Meld.St. nr. } 23 \text { (2011-2012) Visuell kunst/ } \\
\text { Visual Arts }\end{array}$ & $\begin{array}{l}\text { Oslo: Ministry } \\
\text { of Culture }\end{array}$ & $\begin{array}{l}\text { White } \\
\text { paper }\end{array}$ \\
\hline
\end{tabular}




\begin{tabular}{|l|l|l|l|}
\hline 2012 & Meld.St. nr. 7 (2012-2013) Arkiv/Archive & $\begin{array}{l}\text { Oslo: } \\
\text { Ministry of } \\
\text { Culture }\end{array}$ & $\begin{array}{l}\text { White } \\
\text { paper }\end{array}$ \\
\hline
\end{tabular}

The green paper "Museum, Diversity, Memory, Meeting-place" (Ministry of Culture 1996) was presented to the Ministry of Culture in 1996 and has been a reference point for policy discussions on museums in Norway up until this day. The report highlights the relevance or utility of museums to society ("samfunnsnytten") and their potentialities as meeting places or "dialogue institutions". While the term digitalization is not employed in the report, it features discussions on the use of information and communication technologies (ICT) in museums, and the concept of the "information society" is central to the reports' explication of museums potential roles as a dialogue institution.

The concept of the information society is accorded an important role as well in the first Norwegian white paper that deals specifically with digitalization and the cultural heritage field, as is indicated by the title "Sources of knowledge and experience. On archives, libraries and museums in an ICT-age ..." (Ministry of Culture 1999). The white paper affirms the main arguments of the preceding green paper, while accentuating the significance and value of cultural heritage organizations responsiveness to "users" and users' access to knowledge and information. An important difference between the two documents is that whereas the discussions of the green paper implicitly affirms the uniqueness of museums as organizations, the white paper highlights the shared identity of archives, libraries and museums as "cultural heritage organizations". For these reasons, the white paper has become known colloquially as the "ALM-paper".

The next state issued policy document that featured discussions on digitalization and the cultural heritage sector is a so-called "culture report", "Cultural Policy Toward 2014" (Ministry of Culture 2003), presented by the Ministry of Culture to the Parliament in August 2003. ${ }^{2}$ While the topic of cultural heritage is relegated to a subchapter only, the document affirms the continued importance of digitalization in the ALM-sector as well as the goals and priorities formulated in the preceding ALM-paper. More specifically, "Cultural Policy Toward 2014" affirms the recommendation from the ALM-paper that a status report should be produced on issues related to digitalization and the ALM-sector, and further that the report should be a responsibility of the newly established directorate ALM-development (ABM-utvikling $[\mathrm{NO}])^{3}$

In response to this recommendation, the report "Cultural Heritage for All-Digitalization in the ALM-Sector" (ABM 2006) was published by the directorate three years later. As is indicated by the title, this is the first policy document issued by a state authority for the ALM-sector devoted exclusively 
to the topic of digitalization. The report affirms goals formulated in previous documents regarding the importance of users' access to information and knowledge from ALM-organizations, and it details the various categories of users ALM-organizations may relate to in this regard. For the most part, the document deals with technical challenges related to digitalization and the allocation of tasks and responsibilities between actors in the ALM-sector in seeking to solve these challenges.

In April 2009, the Ministry of Culture presented the white paper "National Strategy for Maintenance and Dissemination of Digital Cultural Heritage" (Ministry of Culture 2009b), often simply referred to as the "digitalization paper" by actors in the ALM-sector. While the aims and purposes of the white paper are parallel to those of the report issued by ALM-development, it is couched in a more visionary tone and introduces several concepts that were novelties within this domain of policy. The vision underlying the ICT-policy for the culture sector, it is stated, is to "make as much as possible of the collections available to as many users as possible. The collections should be searchable and available across the whole of the ALM-sector, and the content should be disseminated in a user-friendly manner" (Ministry of Culture 2009b: 9). Inspired by policy documents from other sectors, the white paper introduces the concepts of "digital society", "digital common" and "knowledge common". References are also made to Paragraph 5 of Article 100 (the freedom of speech article) of the Norwegian Constitution, which states that "the state authorities shall create conditions that facilitate an open and enlightened public discourse".

A white paper on libraries and digitalization, entitled "Libraries. Public Knowledge, Meeting Place and Cultural Arena in a Digital Age" (Ministry of Culture 2009a) was presented the same year. The paper is set in the perspectives of the previously mentioned documents, arguing that "the technological development challenges the libraries at the same time as it opens for innovation" (Ministry of Culture 2009a: 29). The user perspective is prevalent in the document that notes how new digital services are developed with the users in mind, instead of the organizations or the experts. At the same time, the white paper also addresses challenges related to administering information in a responsible manner, the amount of time it will take to digitize collections, and the issues related to digital access among different social strata of society-the "digital divide".

A third white paper titled the "The Museum of the Future" (Ministry of Culture 2009c), was presented by the Ministry of Culture to the Parliament in 2009. Tasks related to making digitalized catalogues accessible for a wider audience are highlighted in the document. It is stated that " $t]$ he catalogues were originally only intended for the scientists and other employees at the museums, and it is a big challenge to present catalogues in a form that can function for different types 
of users" (Ministry of Culture 2009c: 149). In the paper, a distinction is made between making collections accessible and disseminating the content to a wider audience. It is argued: "While making the collections accessible is about providing access to the material and objects in the museums, dissemination is about actively adapting content, form, message, and choice of channels etc. to specific target groups. There is a big leap from digital accessibility to digital dissemination" (Ministry of Culture 2009c: 156).

The use of digital technology for dissemination purposes has remained an important topic in the cultural policy discourse on ALM-organizations. In a white paper on the visual arts (Ministry of Culture 2012a) from May 2012, many examples of successful usage of digital technology as part of dissemination strategies were presented. The document points towards the democratizing aspects of technological advances. Some challenges related to the preservation of digitally produced art are also addressed (Ministry of Culture 2012a: 180). The most recent white paper dedicated to ALM-organizations and digitalization was presented before the Parliament by the Ministry of Culture in November 2012 (Ministry of Culture 2012b). The discussions in this white paper, which has the title "Archive", are confined mostly to technical aspects related to archiving and dissemination. ${ }^{4}$

\section{The Emergence of the Digitalization Imperative in Norwegian Policies on Archives, Libraries and Museums}

Having introduced the chain of documents where the policy discourse on digitalization and ALM-organizations is manifested, we will now draw out more clearly the contours of this discourse. We have seen that from the mid-1990s to the mid-2000s digitalization went from a secondary concern into a principal topic of ALM-policy discourse. In the course of this period, digitalization was no longer seen as a contextual factor that should be "taken into account" when addressing other more pressing matters, but emerged as a development that must be addressed in its own right and that calls for immediate responses from all actors that belong to the sector. Digitalization became a policy imperative. It is noticeable in this regard that, unlike discourses on digitalization in other sectors of policy, this accentuation of the importance ascribed to digitalization did not necessarily take the form of a rhetorical escalation. The ALM policy documents under consideration are generally couched in a tone of sobriety and geared towards the practical implications of digitalization within the sector. In most cases, the documents contain a section that affirms the goals for policies on digitalization and that point to potential dangers and future rewards that may ensue from this. Having stated these goals and visions, the documents move on to lengthy discussions on the allocation of practical tasks and responsibilities between the 
actors of the sector in relation to the digitalization agenda. This is in line with Valtysson's (2017) findings in his study of Danish cultural policy discourses on digitalization.

We have seen also that the emergence of digitalization as a policy imperative in these documents coincided with several other discursive developments. One such coincidence is the emergence and solidification of archives, libraries and museums - or the cultural heritage field - as a discrete conceptual and organizational entity. One may point to several reasons for the emergence and solidification of "the ALM" around this time. However, as is explicated in the "ALM-paper" from 1999 (Ministry of Culture 1999), this development was in part predicated on perceived implications of digitalization. The opportunities digitalization represents for users' access to collections online, it is argued in the white paper, reduces the differences in modum operandi between archives, libraries and museums. At the same time, the document notes, the many common technical challenges these organizations face when it comes to the implementation of the digitalization agenda necessitate a greater degree of cooperation and coordination between archives, libraries and museums.

Another coincidence we have heeded to is the rise to prominence of "the user" in ALM-policy discourse. The user-perspective is highlighted in all of the documents under consideration. Whereas the principal tasks of cultural heritage organizations previously was seen to lie in the preservation of objects, and in the provision of "top-down" popular education to the public, it is argued in the documents that these tasks are now to be found in the organizations interactive relations to users. The principle task lies in the organizations responses to users variegated needs and interests for information and knowledge, and intellectual and emotional experiences. This concern with interactive relations between cultural heritage organizations and users is by no means a new development in the cultural heritage sector, or a development that comes into being as a result of digitalization. Rather, digitalization paves the way for an accentuation and redefinition of the user perspective, as it allows one to envisage new opportunities for the democratization of ALM-organizations. This may be specified as a straightforward matter of users' digital access to the collections of ALM-organizations, as a matter of new forms of dissemination associated with digitalization, or as a matter of a digital reconfiguration of boundaries between users and experts.

While these observations provide us with a background understanding of the discourse on digitalization and ALM-organizations, they do not clarify what forms of cultural processes that accounts for the elevation of digitalization into a policy imperative, and to the mystification of technology in Norwegian policies in archives, libraries and museums. To arrive at answers to this question we must look more carefully at the makeup of the discourse. We will do so in three parts. First, 
we will consider processes of institutional isomorphism. Then we will analyze the framing of the discourse. Lastly, we will investigate whether digital technology can be considered a fetishized object in the policy discourse.

\section{Mimetic Processes and Cultural Policies}

In their classic article DiMaggio and Powell (1983) argues that the engine of organizational rationalization has shifted, as "structural change in organizations seems less and less driven by competition or by the need for efficiency. Instead, (...) organizational change occur as the result of processes that make organizations more similar without necessarily making them more efficient" (p. 147). A driving force in processes of institutional isomorphism, is organizational actors striving for legitimacy by way of projecting images of themselves as up-to-date organizations onto their environments. Early adopters of organizational innovations are likely to be driven by a desire to enhance efficiency and competitive advantages. However, as an innovation proliferate within an organizational field a threshold is reached, "beyond which adoption provides legitimacy rather than improves performance" (DiMaggio \& Powell 1983: 148). The neo-institutional perspective has been applied widely to account for organizational change within the culture sector in various countries. Organizations from the state sponsored culture sector are characterized by having complex and contradictory goal structures, with pressures coming from the state, the art worlds, and the public (Larsen 2016). Given that institutional isomorphism is engendered under conditions of uncertainty and ambiguity, these organizations can be assumed to be prone to engage in such processes.

DiMaggio and Powell highlight coercive isomorphism, normative pressures and mimetic processes as mechanisms that engenders institutional isomorphism. When it comes to understanding the emergence of digitalization as a policy imperative in the ALM-field, the mechanism of mimetic processes is of particular relevance. In their historiographic account of state cultural policy in Norway since 1814, Dahl and Helseth (2006) highlight imitation as one of the mechanisms that has shaped this domain of public policy over time. Many, if not most, of the policy objectives and measures that have been introduced by the Norwegian government within this sector, they note, have been modelled on existing arrangements in other countries. While imitation can be assumed to enter into the generation of cultural policy everywhere, such processes can be expected to be particularly prominent in small and peripheral countries, such as Norway. A recent testimony to this tendency is found in the Norwegian governments efforts to promote cultural diversity and the rights of minorities in the domain of cultural policy. Henningsen et al (2010) note how objectives and measures formulated by the Ministry of Culture in this connection were imitations of policy measures from 
other countries. They note also how a "downloading" of concepts and language extracts from international policy documents entered into the formulation of national policies on this subject matter.

A similar tendency is in evidence in the discourse on digitalization in the Norwegian ALM-field. A backdrop to many of the arguments presented in the white papers and reports under consideration in this study is an understanding that in other countries policies dealing with digitalization are already in place and that to "catch up" with this new reality is an impending task of Norwegian ALM-organizations. Several of the documents include quotations from UNESCO-documents and other international sources that underscore the need for development of policies to tackle the challenges and opportunities posed by digitalization in the ALM-sector. However, mimetic processes are not restricted to imitation of cultural policy elements from the international arena. In several of the documents reference is made to policy initiatives, concepts and goals that originate from other domains of public policy, such as the industry and commerce sector, the communications sector and the research and education sector. A further potential source of imitation in these documents, is other subsectors within the culture sector that have developed more elaborate policies on digitalization for reasons of practical necessity, such as the commercial music industry and the news media.

Thus, in accordance with the neo-institutional perspective, one may view the elevation of digitalization into a policy imperative in the ALM-sector as a result of institutional isomorphism or, more specifically, as a result of mimetic processes. However, while this is a plausible analysis, it does not by itself account for the special priority that is ascribed to digitalization when compared to other developments that is seen to impinge on the policy field. Why is it that this particular form of development acquires the role of a policy imperative, at the expense of other emergent developments? From what sources is the sense of urgency that accrues to the topic of digitalization in the ALM-field derived? To deepen the understanding of the emergence of digitalization as a policy imperative within the ALM-field, we will look more closely at the discursive framing of the topic of digitalization in the documents under consideration.

\section{The Epochalist Framing of the Discourse on Digitalization and the ALM-sector}

Framing refers to conceptual structures-metaphors, images, narrativesthat are evoked in communication about a phenomenon and that impress a simplified understanding of the phenomenon onto communication participants (Bateson 1972, Goffman 1974, Lakoff 2010). Framing analysis has been applied 
to explain the mobilizing powers of discourses espoused by social movements, by demonstrating how such discourses provide adherents with compelling diagnostics of their current grievances and with utopian prognostic visions of the future (cf. Henningsen \& Jones 2013, Snow \& Benford 1988). When it comes to contemporary discourses on digitalization, a consideration of their epochalist framing is of particular relevance.

According to du Gay (2003), epochalism is a discursive form that describes and explains social change on the basis of dichotomized schemes of periodization, e.g. by accentuating the contrast between the "analogue" culture of the past and the "digital" culture of the future. It is in other words, a form of discursive framing that highlight a sense of the present as moment of historical rupture, where an established "old" order of society is rapidly giving way to an emerging "new" order of society. By evoking fear-inducing images of the future along with images of potential future prosperity, epochalist discourses may take on a hortatory or mobilizing role, as urgent calls for action.

As Kaufmann and Jeandesboz (2017) point out, such epochal visions are a pervasive feature of contemporary discourses on "the digital" in many domains of policy. This applies to academic as well as popular discourses, which tend generally to be ripe with declarations about the era-defining and transformative consequences of digitalization. A similar tendency is detectable in the discourse on digitalization in the ALM-field, as already hinted to by Hylland (2017). The epochalist framing is revealed most clearly in the titles of some of the white papers, which allude to the present as an "age" of digitalization ("Sources of Knowledge and Experience: On archives, Libraries and Museums in an ICT-age", "Libraries: Public Knowledge, Meeting Place and Cultural Arena in a Digital Age"), and in the use of concepts such as "information society" and "digital society" in the documents. Furthermore, such a frame is revealed also in the documents' highlighting of the potential dangers and rewards of digitalization. It is noticeable in this regard how utopian and dystopian images of digitalization tie in with legitimation of ALM-organizations, as they serve to underscore the continued relevance and need for these organizations in society's digital future.

One set of dangers associated with digitalization evoked in the documents are those of fragmentation and overload of information. While digitalization creates infinite possibilities for users to access information, it is argued, users may lack the competence and means required to access information, they may become overwhelmed by the masses of information at hand, they may become disoriented because of the fragmented nature of digital information and they may become mislead by false information. This affirms the need for ALM-organizations as authorities that can ensure quality (truthfulness, authenticity, relevance) of knowledge and information. It affirms also the need for ALM-organizations 
that, through dissemination and interactive relations with users, can provide guidance on how to access knowledge and place information in contextual frameworks that foster learning and critical thinking. Thus, when the documents under consideration highlight the dangers and dystopian tendencies associated with digitalization, they at the same time highlight people's enhanced need for ALM-organizations and posits these as a "counterweight", as one documents puts it, to the present and future dangers of digitalization.

On the other hand, the documents appeal to utopian desires aroused by digitalization, by pointing to its potential as a means of realizing overarching policy goals of democratization of access to culture within the context of ALM-organizations. Digitalization's role as a tool of democratization may refer simply to enhanced access to cultural products for everyone, as people may now increasingly access the collections of ALM-organizations by way of electronic devices and regardless of their physical location. In a slightly different manner, it may refer to possibilities for the fulfilment of constitutional requirements relating to freedom of information and expression (Ministry of Justice and the Police 1999; Rønning 2016), and hence to promote deliberative democracy. In this context, democratization can furthermore refer to how digitalization help create new possibilities for popular participation, by paving the way for the prosumer role (Ritzer, Dean \& Jurgenson 2012, Toffler 1980) and interactive relations that transcend boundaries between experts and users. Thus, when the documents highlight the utopian potentialities of digitalization within ALM-organization, they also highlight its role as a potential remedy for the historical failures of these organizations to realize goals of universal access to culture.

By looking at the dystopian and utopian visions on digitalization we can understand the sense of urgency that attaches to discourses on digitalization and their power and persuasiveness as calls for immediate action. However, while this is a line of analysis that is supported by research from other sectors of society, there are reasons to caution against placing too much weight on it in the context we are dealing with in this article. While the documents under consideration clearly evoke the widespread epochal discursive frame (even though the documents for the most part are couched in a tone of sobriety), it would be misleading to say that this permeates the discourse on digitalization and the ALM-field. If we are to arrive at a satisfactory understanding of the cultural processes that enters into digitalization's makeup as a policy imperative, we must also consider how digital technology becomes a fetishized object in the policy discourse. 


\section{The Fetishism of Digital Technologies in the Discourse on Digitalization and the ALM-sector}

In order to flesh out this argument, we will return to one of the documents in the chain of whitepapers and reports presented above. The report "Cultural Heritage for All" (ABM 2006) was the first among these policy documents that was devoted exclusively to the topic of digitalization. The report is highly illustrative of the sober tone in which the discourse on digitalization and ALM-organizations is often kept. The report's introductory chapter notes how digitalization carries a potential for increased user access to collections. Apart from this, the one hundred and twenty pages of the document is characterized by a complete absence of visionary talk about digitalization. Instead, the report takes the form of a catalogue of specified technical tasks that must be carried out in order to utilize the potentials of digital technology in the ALM-sector and the allocation of responsibility for the execution of these tasks among the actors of the sector. At no point does the document halt to ask whether or how the massive task of bringing ALM-organizations up to date with the possibilities of digital technology is justified. Rather, this circumstance is treated as a self-explanatory fact and a point of departure for the report's "to do-list" of practical tasks related to the digitalization agenda. In this way, the report attests more firmly than any of the other documents under consideration -including those that evoke grand visions about the future rewards of uses of digital technologies - to the imperative role that is attached to digitalization. While the report refrains almost completely from placing digitalization into a legitimating narrative frame, digitalization nevertheless emerges as an object that dictate action by its mere mentioning.

What is suggested by these observations is that there is a third form of mystification at work in the discourse on digitalization in the ALM-field, which is different from the forms of mystification discussed in the previous sections. This does not take the form of a utopian/dystopian narrative about epochal change or about the need to catch up with international developments, rather it is a tendency of fetishism, the process whereby people come to view objects they have created or appropriated for their own purposes as "powers imposed on us" (Graeber 2005: 427). What distinguishes fetishism from other forms of ideological mystifications, Eagleton (1991) notes, is that it is not a narrative that is put forward to justify actions or social arrangements, but a misconception of the world that arises "objectively" from certain forms of social practices. In Marx' (1906) famous discussion of commodity fetishism, this concerns specifically the tendency in capitalist society that the value of commodities comes to be viewed as an inherent property of these things, and that their social character thereby is rendered invisible. Other analysts have elaborated on this discussion to analyze broader processes of reification or abstraction in modern capitalist society (Sayer 1991), such as the tendency that 
"the economy" emerges as a unitary and autonomous force that is external to social relations and that impinges on society. More specifically, the concept of fetishism has been used to understand how technology or technological systems come to be viewed "as a powerful and autonomous agent that dictates the patterns of human social and cultural life" (Pfaffenberger 1988: 239). To relate to digital technology as a force that is external to the world of social relations and that impinge on this world from the outside and dictate action on the part of people, would be an example of fetishism of technology. Clearly, the discourse on digitalization in the ALM-field is an instance of such a form of fetishism. In the policy documents under consideration in this study, there is a tendency that digitalization emerges as an autonomous force or agent that in and of itself calls for an immediate response from actors and organizations in the ALM-sector.

However, as we have indicated, this form of mystification is not an unequivocal tendency of the discourse on digitalization in the ALM-field. Again, the report "Cultural Heritage for All" is symptomatic of this discourse in that it invokes the concept of digitalization in two distinct senses. On the one hand, digitalization is talked about in the singular, as a unitary force or entity that is equipped with autonomous powers. In these cases, one may reasonably say that the discourse exhibits a tendency of fetishism of technology. On the other hand, digitalization is talked about in the plural, in reference to a multitude of specified technical means that enter the production, dissemination, storage and consumption of cultural material and in reference to processes and tasks of implementing and utilizing these technical means. When talked about in this way, digitalization is effectively demystified and emerges as an integral feature of the social world in which ALM-organizations are situated. It is dissolved into innumerable opportunities for technical improvements and the often highly practical tasks that must be in effect if actors of the sector are to reap the rewards made possible by digitalization.

To account for this circumstance, we find Graeber's (2005) discussion of fetishism to be particularly helpful. Graeber's understanding of fetishism is broader than Marx' concept of commodity fetishism and the abovementioned theories that are derived from this. In Graeber's rendering, fetishism is not confined to modern capitalist society, but is rather viewed as a cultural tendency that is present in all kinds of social formations. To Graeber, fetishism is a form of proto-religious belief, or "a god under construction", as he terms it (2005: 427). This may take various forms. Fetishism, he argues, consists of beliefs and practices that arise in connection with "social creativity", or the emergence of new social arrangements. It is a way in which human agents deal with such novelties and convert them into conceptually manageable features of the worlds they inhabit. Graeber's understanding of fetishism as a form of mystification is more dynamic than that of the abovementioned analysts. At the one extreme, he notes, fetishism may 
simply consist in the recognition that emergent social arrangements exert power over people that enter into them, in which case there is hardly reason to speak about mystification at all. ${ }^{5}$ At the other extreme, fetishism can take the form of an unquestioned belief that, for instance, "the laws of the market" make up a system that is "natural, immutable, and therefore completely outside any possibility of human interventions" (Graeber 2005: 429). Thus, on Graeber's account, fetishism may or may not involve processes of mystification. Also, he challenges the view of fetishism as a permanent state of misconception of reality that works its way wholly "behind the backs" of people. Reviewing various ethnographic examples, Graeber notes how persons who, on certain occasions, exhibit fetishized beliefs about rituals and ritual objects, at other times demonstrate demystified understandings of the social nature of the same phenomena. It is only when fetishism is turned into an explicitly formulated theology that this alternation between mystification and demystification is brought to a halt, Graeber argues.

Transferred to our empirical case, these theoretical assertions alert us to the ways in which fetishism enters into the discourse on digitalization in the ALM-field. The alternation between references to digitalization in the singular and in the plural that characterize the "Cultural Heritage for All" report and the other policy documents we have considered conforms to the general process of fetishism described by Graeber. It is an alternation, one may say, between moments of mystification and moments of demystification. In the first instance, the social character of digital technology is rendered invisible and digitalization emerges as an externally imposed imperative for action. In the second, digital technology is situated in the mundane reality of social relations and appears rather as a collection of tools that may or may not be employed for useful purposes.

\section{Conclusion}

In recent years, a growing body of studies that deal with digitalization and cultural heritage have emerged, particularly within the disciplines of information science, law, and computer science. As noted by Thylstrup (2019), these studies have been geared towards technology or information policy issues rather than the exploration of theory, and they have tended to problematize the "hows" rather than the "whys" of processes associated with digitalization. In this article, we have sought to contribute to fill this knowledge gap in studies of digitalization of cultural heritage, through the application of classical social theories on cultural processes. Our aim has been to throw light on the question of how and by what forms of cultural processes digitalization is constituted as a policy imperative within the ALM-policy-field. In order to do so, we have examined policy documents from the late 1990s and onward that deal with digitalization and the ALM-field. As 
the analysis has shown, there are several cultural processes that can account for the concept of digitalization achieving the status of policy imperative in the ALM-field and digital technology becoming mystified in the policy discourse. We have argued that the most important processes behind the rise of the digital imperative is related to mimesis, epochalism and fetishism. These processes will also be relevant to consider for those seeking to understand why digital technology today is considered such a central topic in most policy areas.

Erik Henningsen has a $\mathrm{PhD}$ in social anthropology from the University of Oslo. He is research director at The Department for Welfare, Democracy and Governance at the Norwegian Institute for Urban and Regional Research, Oslo Metropolitan University. His research interests include cultural policy, work life studies and studies of professions. E-mail: erik.henningsen@oslomet.no

Håkon Larsen is a professor at the Department of Archivistics, Library and Information Science, Oslo Metropolitan University. He holds a PhD in sociology from the University of Oslo. He has published a number of books and articles on cultural sociology, cultural policy and ALM-institutions. E-mail: hakon.larsen@ oslomet.no

\section{Acknowledgement}

This research has been carried out as part of the research project Archives, Libraries, Museums, Digitalization, and the Public Sphere (ALMPUB), funded by the Norwegian Research Council (Grant number 259052).

\section{Notes}

1 Thus, Borghi \& Karapapa (2013) notes that "(t)his unprecedented empowering of the reading experience with the accumulation of all the world's knowledge in electronic format, and with all possible associations that can be made by exploring the computational potential of this knowledge, is what mass digitization promises to achieve. This achievement is frequently put forward as conclusive evidence of public utility. In this vein, having all books and other copyright content searchable online appears to be the necessary condition to make them part of cyber-space, with all its connotations as a breeding ground for democracy and progress in the information society. It is no surprise, therefore, that a purely technical operation such as scanning books has even been seen as a 'moral imperative' and a 'moral obligation"' (p.10).

2 Since the 1970s, Norwegian governments have, at intervals of about a decade, presented white papers that make broad assessments of developments within the culture sector and signals future directions for the country's cultural policies. 


\section{Culture Unbound}

Journal of Current Cultural Research

3 The establishment of this directorate in 2003 was a material outcome of the ALM-paper from 1999, and a creation of the Ministry of Culture and the Ministry of Church Affairs, Education and Research. The directorates' mission was to administer and develop issues related to all three types of organizations. Following a re-organization, the directorate ceased to exist already in 2011, with archival and museum issues being directed to the Arts Council, and the library issues directed to the National Library.

4 In addition, a new "culture report" was presented in 2018, but as our analysis was finished prior to this date, it does not make up part of our data.

5 As Graeber (2005: 431) notes in this regard: "If fetishism is, at root, our tendency to see our own actions and creations as having power over us, how can we treat it as an intellectual mistake? Our actions and creations do have power over us. This is simply true".

\section{References}

ABM(2006): Kulturarven til alle-digitalisering iabm-sektoren, Oslo:ABM-utvikling. Bateson, Gregory (1972): Steps to an Ecology of Mind, London: Jason Aronson Inc. Borghi, Maurizio, \& Karapapa, Stavroula (2013): Copyright and Mass Digitization, Oxford: Oxford University Press.

Caswell, Michelle, Harter, Christopher, \& Jules, Bergis (2017): “Digital histroical record: integrating community archives in national strategies for access to Digital Cultural Heritage," D-Lib Magazine, 23:5/6, doi: https://doi.org/10.1045/ may2017-caswell

Dahl, Hans Fredrik, \& Helseth, Tore (2006): To knurrende løver: kulturpolitikkens historie 1814-2014, Oslo: Universitetsforlaget.

DiMaggio, Paul J., \& Powell, Walter W. (1983): "The iron cage revisited: institutional isomorphism and collective rationality in organizational fields," American Sociological Review, 48:2, 147-160.

du Gay, Paul (2003): "The tyranny of the epochal: change, epochalism and organizational reform," Organization, 10:4, 663-684.

Eagleton, Terry (1991): Ideology: An Introduction, London: Verso.

Fidjestøl, Alfred (2015): Eit eige rom. Norsk kulturråd 1965-2015, Oslo: Samlaget.

Goffman, Erving (1974): Frame analysis: an essay on the organization of experience, New York, NY: Harper and Row.

Graeber, David (2005): "Fetishism as social creativity. Or, fetishes are gods in the process of construction," Anthropological Theory, 5:4, 407-438.

Henningsen, Erik, Berkaak, Odd Are, \& Skålnes, Sigrid (2010): Mangfoldsåret: Muligheter og motsigelser i politikken for et flerkulturelt kulturliv, NIBR rapport 18, Oslo: NIBR.

Henningsen, Erik, \& Jones, Peris (2013): “'What kind of hell is this!' Understanding the Mungiki movement's power of mobilisation," Journal of Eastern African Studies, 7:3, 371-388.

Hylland, Ole Marius (2017): "Even better than the real thing? Digital copies and digital museums in a digital cultural policy," Culture Unbound: Journal of Current Culutral Research, 9:1, 62-84.

Kaufmann, Mariele, \& Jeandesboz, Julien (2017): "Politics and 'the digital': From singularity to specificity," European Journal of Social Theory, 20:3, 309-328. 
Lakoff, George (2010): "Why it matters how we frame the environment," Environmental Communication, 4:1, 70-81.

Lakoff, George, \& Johnson, Mark (1980): Metaphors We Live By, Chicago, IL: University of Chicago Press.

Larsen, Håkon (2016): Performing Legitimacy: Studies in High Culture and the Public Sphere, Switzerland: Palgrave Macmillan.

Marx, Karl (1906): Capital: A Critique of Political Economy, New York, NY: The Modern Library.

Ministry of Culture (1996): NOU (1996:7), Museum, mangfald, minne, møtestad, Oslo: Kulturdepartementet.

Ministry of Culture (1999): St.meld. 22 (1999-2000), Kjelder til kunnskap og oppleving. Om arkiv, bibliotek og museum i ei IKT-tid og om bygningsmessige rammevilkår på kulturområdet, Oslo: Kulturdepartementet.

Ministry of Culture (2003): St.meld. 48 (2002-2003), Kulturpolitikk fram mot 2014, Oslo: Kultur- og kirkedepartementet.

Ministry of Culture (2009a): St.meld. 23 (2008-2009), Bibliotek. Kunnskapsallmenning, møtestad og kulturarena i ei digitial tid, Oslo: Kultur- og kirkedepartementet.

Ministry of Culture (2009b): St.meld. 24 (2008-2009), Nasjonal strategi for bevaring og formidling av digital kulturarv, Oslo: Kultur- og kirkedepartementet.

Ministry of Culture (2009c): St.meld. 49 (2008-2009), Framtidas museum. Forvaltning, forskning, formidling, fornying, Oslo: Kultur- og kirkedepartementet.

Ministry of Culture (2012a): Meld.St. 23 (2011-2012), Visuell kunst, Oslo: Kulturdepartementet.

Ministry of Culture (2012b): Meld.St. 7 (2012-2013),Arkiv, Oslo: Kulturdepartementet.

Ministry of Justice and the Police (1999): NOU (1999:27), 'Ytringsfrihet bør finde sted'. Forslag til ny $\$ 100$, Oslo: Justis- og politidepartementet.

Pfaffenberger, Brian (1988): "Fetishised objects and humanised nature: Towards an anthropology of technology," Man, 23:2, 236-252.

Ritzer, George, Dean, Paul, \& Jurgenson, Nathan (2012): "The coming of age of the prosumer," American Behavioral Scientist, 56:4, 379-398.

Rønning, Helge (2016): “On press freedom and other media freedoms," Ulla Carlsson (ed.): Freedom of Expession and Media in Transition: Studies and Reflections in the Digital Age, Gothenburg: Nordicom, 43-51.

Sayer, Derek (1991): Capitalism and Modernity: An Excursus on Marx and Weber, London: Routledge.

Snow, Davis A., \& Benford, Robert D. (1988): "Ideology, frame, resonance, and participant mobilization," Bert Klandermans, Hanspeter Kriesi \& Sidney G. Tarrow (eds): From Structure to Action: Social movement Participation Across Cultures, Greenwich, CT: JAI press.

Thylstrup, Nanna Bonde (2019): The Politics of Mass Digitization, Cambridge, MA: MIT Press.

Toffler, Alvin (1980): The Third Wave, New York, NY: William Morrow \& Co.

Valtysson, Bjarki (2017): "From policy to platform: the digitization of Danish Cultural Heritage," International Journal of Cultural Policy, 23:5, 545-561. 